ROCZNIK ADMINISTRACJI PUBLICZNEJ 2019 (5)

ARTYKUłY Prawo i administracja Unii Europejskiej / Law and Administration of the European Union

DOI 10.4467/24497800RAP.19.012.11475

http://www.ejournals.eu/RAP/

ISSN 2449-7800 (online), ISSN 2449-7797 (druk), s. 188-200

KATARZYNA SZLACHTA-KISIEL'

\title{
Koordynacja systemów zabezpieczenia społecznego w relacjach pochodnych
}

\section{Wprowadzenie}

Przystąpienie Polski do Unii Europejskiej 1 maja 2004 r. było nie tylko aktem politycznym, wpłynęło także na życie społeczne, gospodarcze i prawne. Bardzo wielu Polaków skorzystało z szans stworzonych przez zasadę swobodnego przepływu osób i podjęło pracę w krajach członkowskich Unii Europejskiej oraz w państwach Europejskiego Obszaru Gospodarczego i Szwajcarii. Migracja zarobkowa wiąże się nierozerwalnie z tym, że ubezpieczony w ciągu swojego życia zawodowego podlega kilku przynajmniej systemom zabezpieczenia społecznego, co mogłoby w konsekwencji doprowadzić do groźnej sytuacji, w której nie spełni on warunków do nabycia prawa do świadczenia $\mathrm{z}$ tytułu starości w żadnym z systemów, którym w przeszłości podlegał. Aby umożliwić realizację swobodnego przemieszczania się osób, niezbędna jest koordynacja krajowych systemów zabezpieczenia społecznego, z których korzystają osoby migrujące wewnątrz $\mathrm{UE}^{2}$. Dlatego też bardzo duże znaczenie mają wypracowane przez kraje Unii reguły i zasady koordynacji w zakresie zabezpieczenia społecznego. Ratio legis tej regulacji sprowadza się do założenia, że żaden przebyty okres ubezpieczenia, zamieszkania i zatrudnienia nie będzie pominięty przy rozpoznawaniu wniosku o świadczenie. Samo obowiązywanie mechanizmów koordynacji na obszarze Rzeczpospolitej Polskiej od chwili rozpoczęcia członkostwa Polski w Unii Europejskiej nie jest jednak wystarczające dla zapewnienia ubezpieczonym bezpieczeństwa na tym polu. Ponieważ w ramach Unii Europejskiej nie zdecydowano się na podjęcie działań harmonizujących w zakresie zabezpieczenia społecznego, ustanowiono natomiast prawne mechanizmy koordynacji krajowych systemów zabezpieczenia

1 Mgr Katarzyna Szlachta-Kisiel, doktorantka w Katedrze Prawa Pracy i Polityki Społecznej, Wydział Prawa i Administracji, Uniwersytet Jagielloński.

2 P. Roicka, Skutki swobody przeplywu osób w UE dla krajowych systemów zabezpieczenia społecznego. Wybrane zagadnienia, „Ubezpieczenia Społeczne. Teoria i Praktyka” 2015, nr 3 (126), s. 112. 
społecznego ${ }^{3}$, niezbędne było powołanie do życia polskiego podmiotu oraz stworzenie struktur i procedur, które w sposób kompetentny i sprawny pozwolą na rozpoznawanie wniosków o świadczenia z systemu zabezpieczenia społecznego z zastosowaniem zasad i reguł koordynacji systemów zabezpieczenia społecznego.

Wprowadzenie w życie w Polsce wypracowanych wcześniej przez państwa członkowskie Unii Europejskiej mechanizmów koordynacji systemów zabezpieczenia społecznego nie pozostało bez wpływu na polskie postępowanie przedsądowe $\mathrm{w}$ sprawach $\mathrm{z}$ zakresu ubezpieczeń społecznych. Pozwoliło ono także wskazać lukę w obszarze koniecznego działania instytucji ubezpieczeniowej już po przyznaniu świadczenia, która jest konsekwencją braku koordynacji systemów zabezpieczenia społecznego na tym polu.

Ponieważ materia ubezpieczeń społecznych jest przedmiotowo niezwykle szeroka, w niniejszym artykule ograniczono się do postępowania w przedmiocie poświadczenia życia. Zastosowano metodę analizy dogmatycznoprawnej oraz teoretycznoprawnej, przy uwzględnieniu zasad wykładni językowej, systemowej i funkcjonalnej jako najwłaściwszych do opisania wzajemnych relacji ustawodawstwa unijnego i krajowego.

\section{2. Źródła regulacji unijnej koordynacji systemów zabezpieczenia społecznego}

W dniu akcesji Polski do Unii Europejskiej podstawowymi aktami prawa unijnego $\mathrm{w}$ zakresie koordynacji systemów zabezpieczenia społecznego były rozporządzenie Rady (EWG) nr 1408/71 z dnia 14 czerwca $1971 \mathrm{r}$. w sprawie stosowania systemów zabezpieczenia społecznego do pracowników najemnych, osób prowadzących działalność na własny rachunek i do członków ich rodzin przemieszczających się we Wspólnocie ${ }^{4}$ oraz rozporządzenie Rady (EWG) nr 574/72 z dnia 21 marca 1972 r. w sprawie wykonywania rozporządzenia (EWG) $\mathrm{nr}$ 1408/715. W myśl rozporządzenia nr 1408/71 osoby przemieszczające się na terenie Unii, Europejskiego Obszaru Gospodarczego lub Szwajcarii w celach zarobkowych podlegały ustawodawstwu tylko jednego państwa członkowskiego (tzw. zasada jedności stosowanego prawa). Rozporządzenie to statuowało tym samym generalną zasadę, na podstawie której pracownik najemny oraz osoba prowadząca działalność na własny rachunek (np. pozarolniczą działalność gospodarczą) podlegała ustawodawstwu państwa, w którym miała zatrudnienie lub prowadziła działalność (lex loci laboris).

3 G. Uścińska, Zabezpieczenie społeczne osób korzystających z prawa do przemieszczania się w Unii Europejskiej, Warszawa 2013, s. 162.

4 Dz.Urz. UE L 149, s. 2, ze zm.

5 Dz.Urz. UE L 74, s. 1, ze zm. 
Reforma systemu koordynacji systemów zabezpieczenia społecznego, mająca na celu ich unowocześnienie i uproszczenie, weszła w życie 1 maja 2010 r., a miejsce rozporządzeń nr 1408/71 i nr 574/72 w unijnym porządku prawnym zajęły odpowiednio rozporządzenie Rady i Parlamentu Europejskiego (WE) nr 883/2004 z dnia 29 kwietnia 2004 r. w sprawie koordynacji systemów zabezpieczenia społecznego ${ }^{6}$ - jako nowe rozporządzenie podstawowe oraz rozporządzenie Rady i Parlamentu Europejskiego nr 987/2009 z dnia 16 września 2009 r. dotyczące wykonywania rozporządzenia (WE) $\mathrm{nr} 883 / 2004 \mathrm{w}$ sprawie koordynacji systemów zabezpieczenia społecznego ${ }^{7}$ - jako nowe rozporząazenie wykonawcze. Uzupełnieniem tych regulacji jest rozporządzenie Parlamentu Europejskiego i Rady (UE) nr 1231/2010 $\mathrm{z}$ dnia 24 listopada $2010 \mathrm{r}$. rozszerzające rozporządzenie (WE) nr 882/2004 i rozporządzenie (WE) nr 987/2009 na obywateli państw trzecich, którzy nie są jeszcze objęci tymi rozporządzeniami jedynie ze względu na swoje obywatelstwo ${ }^{8}$.

Rozporządzenie nr 883/2004 wskazuje, że zasada jednego ustawodawstwa ma wielkie znaczenie i powinna być wzmocniona, wprowadza nakaz równego traktowania świadczeń, dochodów, okoliczności lub zdarzeń oraz zasadę sumowania okresów ubezpieczenia9 .

Rozporządzenia te, stanowiące jedynie wycinek acquis communautaire, są stosowane przez państwa członkowskie Unii Europejskiej, a od 1 kwietnia 2012 r. stosuje je również Szwajcaria. Do 31 marca 2012 r. Szwajcaria stosowała przepisy rozporządzenia $\mathrm{nr} 1408 / 71$ oraz $\mathrm{nr} 574 / 72$. Co istotne, przepisy tych rozporządzeń są nadal stosowane przez państwa EOG - Norwegię, Islandię i Liechtenstein - w przypadku gdy praca, niezależnie od jej udziału, jest wykonywana równocześnie na terenie państw członkowskich UE, na terenie Szwajcarii oraz państw EOG ${ }^{10}$. Status obowiązującego zachowało także rozporządzenie Rady (WE) nr 859/2003 z dnia 14 maja $2003 \mathrm{r}$. rozszerzające przepisy rozporządzenia (EWG) nr 1408/71 i rozporządzenia 574/72 na obywateli państw trzecich, którzy nie są jeszcze objęci tymi przepisami wyłącznie ze względu na ich obywatelstwo ${ }^{11}$.

W oparciu o taki katalog źródeł prawa w zakresie unijnej koordynacji systemów zabezpieczenia społecznego wskazać należy na dwie cechy unijnej koordynacji:

6 Dz.Urz. UE L 166, s. 1, ze zm.

7 Dz.Urz. UE L 284, s. 1, ze zm.

8 Dz.Urz. UE L 344, s. 1.

9 K. Ślebzak, Koordynacja systemów zabezpieczenia społecznego, Warszawa 2012, s. 44 .

10 Ustalanie właściwego ustawodawstwa na podstawie rozporządzeń 1408/71 i 574/72, https://www.zus.pl/pracujacy/pracujacy-w-ue-eog-szwajcarii/archiwum/ustalanie-wlasciwego-ustawodawstwa-na-podstawie-rozporzadzen-1408/71-i-574/72 (dostęp: 29.04.2019).

11 Dz.Urz. WE L 124, s. 1. 
1) system źródeł, łącznie z krajowymi przepisami wewnętrznymi, opiera się na prawie ponadnarodowym - unijnym, które ma prymat nad nimi;

2) techniki koordynacji i ich usytuowanie w praktyce odpowiadają i podążają za celami zawartymi w postanowieniach Traktatu o funkcjonowaniu Unii Europejskiej (TFUE) ${ }^{12}$, na podstawie których odpowiednie normy zostały ustanowione ${ }^{13}$.

Zgodnie $\mathrm{z}$ art. 288 zdanie drugie TFUE rozporządzenie ma zasięg ogólny, wiąże w całości i podlega bezpośredniemu zastosowaniu we wszystkich państwach członkowskich UE. Cecha bezpośredniości obowiązywania rozporządzeń oznacza, że wiążą one z chwilą wejścia w życie, nie jest bowiem konieczny dla ich mocy obowiązującej akt inkorporacji zawartych w nich treści do prawa wewnętrznego państw członkowskich. Rozporządzenie unijne o koordynacji systemów zabezpieczenia społecznego cechuje jednocześnie:

1) wewnętrzna stosowalność, która oznacza wykorzystywanie rozporządzenia wewnątrz Unii Europejskiej dla zapewnienia koordynacji systemów zabezpieczenia społecznego między państwami członkowskimi Unii Europejskiej na podstawie TFUE;

2) zewnętrzna stosowalność, która oznacza wykorzystanie rozporządzenia dla zapewnienia koordynacji systemów zabezpieczenia społecznego na zewnątrz Unii Europejskiej między państwami członkowskimi Unii Europejskiej a innymi państwami (niebędącymi członkami UE) na podstawie umów międzynarodowych zawartych przez Unię Europejską (i przez państwa członkowskie) z tymi państwami ${ }^{14}$.

W sprawach odnoszących się do stosowania krajowych systemów zabezpieczenia społecznego wobec pracowników i członków ich rodzin przemieszczających się w obrębie Unii Europejskiej rozporządzenia nie ustanawiają praw z zakresu zabezpieczenia społecznego. Koordynują krajowe systemy zabezpieczenia społecznego, w których powyższe uprawnienia zostały uregulowane ${ }^{15}$. Praktycznym skutkiem bezpośredniego stosowania rozporządzeń Rady i Parlamentu Europejskiego w sprawie koordynacji systemów zabezpieczenia społecznego są procedury postępowania przyjęte przez krajową instytucję zabezpieczenia społecznego przy rozpoznawaniu wniosków o świadczenia, jakie każdy z krajów członkowskich, w tym także

12 Wersja skonsolidowana Dz.Urz. UE z 2016 r. C 202, s. 47.

13 A. Szybkie, Zwalczanie błędów i nadużyć związanych z koordynacja systemów zabezpieczenia społecznego w Unii Europejskiej na przykładzie przeciwdziałania nadpłatom emerytur na zagraniczne rachunki bankowe, „Ubezpieczenia Społeczne. Teoria i Praktyka" 2018, nr 2 (137), s. 21.

14 A. Szybkie, Materialnoprawny wplyw koordynacji systemów zabezpieczenia spotecznego UE na krajowe instytucje prawne zabezpieczenia społecznego, „Ubezpieczenia Społeczne. Teoria i Praktyka" 2017, nr 4 (135), s. 8-10.

15 A.M. Świątkowski, Obywatelstwo Unii Europejskiej a prawo do świadczeń z zabezpieczenia społecznego, „Studia z Zakresu Prawa Pracy i Polityki Społecznej” 2008, s. 63. 
Polska, musiał wypracować i stosować, mając na uwadze wszelkie zasady i mechanizmy wynikające wprost $\mathrm{z}$ tych rozporządzeń.

\section{Polska struktura organizacyjna na potrzeby unijnej koordynacji}

Konsekwencją bezpośredniego stosowania regulacji dotyczących koordynacji systemów zabezpieczenia społecznego było wyznaczenie w polskim systemie ubezpieczeń społecznych instytucji, której zadaniem było przejęcie tej koordynacji na terytorium Rzeczpospolitej Polskiej. Natura rerum obowiązki te przejął Zakład Ubezpieczeń Społecznych. Po wejściu w życie w 2010 r. reformy systemu koordynacji systemów zabezpieczenia społecznego i powstaniu konieczności wprowadzenia podstaw prawnych do posługiwania się Systemem Elektronicznej Wymiany Informacji (EESSI) wprowadzono do ustawy z dnia 13 października 1998 r. o systemie ubezpieczeń społecznych ${ }^{16}$ art. $68 \mathrm{a}^{17}$, zgodnie z którym do zakresu działania Zakładu Ubezpieczeń Społecznych należy prowadzenie punktu kontaktowego, o którym mowa w rozporządzeniu nr 987/2009, służącego do wymiany danych w ramach Systemu Elektronicznej Wymiany Informacji (EESSI) dotyczących zabezpieczenia społecznego w zakresie:

1) określania ustawodawstwa mającego zastosowanie;

2) świadczeń pieniężnych z tytułu choroby;

3) świadczeń z tytułu macierzyństwa i równoważnych świadczeń dla ojca;

4) świadczeń z tytułu inwalidztwa;

5) świadczeń z tytułu starości;

6) rent rodzinnych;

7) świadczeń pieniężnych z tytułu wypadków przy pracy i chorób zawodowych;

8) zasiłków na wypadek śmierci;

9) świadczeń przedemerytalnych;

10) specjalnych świadczeń pieniężnych o charakterze nieskładkowym;

11) odzyskiwania należności z tytułu składek lub nadpłaconych świadczeń.

W zakresie tym ZUS jest instytucją właściwą, instytucją miejsca zamieszkania, instytucją miejsca pobytu, o których mowa w rozporządzeniu nr 883/2004.

Ustawodawca polski nie wprowadził definicji legalnej pojęć związanych z funkcjami, jakie pełni Zakład Ubezpieczeń Społecznych na podstawie rozporządzeń w sprawie koordynacji oraz ustawodawstwa polskiego, ponieważ definicje te zawarte są w rozporządzeniach nr 883/2004 oraz 987/2009. Ustawodawca zdecydował, że wszystkie te funkcje pełnić będzie

16 Obecny tekst jedn.: Dz.U. z 2019 r. poz. 300 ze zm.

17 Ustawą z dnia 8 listopada 2013 r. o zmianie niektórych ustaw w związku z wdrożeniem Systemu Elektronicznej Wymiany Informacji dotyczących Zabezpieczenia Społecznego na terytorium Rzeczypospolitej Polskiej, Dz.U. poz. 1623. 
Zakład Ubezpieczeń Społecznych za pośrednictwem swoich jednostek organizacyjnych. Definicje obejmują pojęcia instytucji łącznikowej, instytucji właściwej oraz instytucji miejsca zamieszkania.

Zakład Ubezpieczeń Społecznych pełniący funkcję instytucji łącznikowej, wyznaczonej przez właściwą władzę państwa członkowskiego, jest uprawniony do bezpośredniego porozumiewania się z inną instytucją łącznikową realizującą zadania dotyczące uzgadniania zasad współpracy i procedur wykonawczych oraz do wyjaśniania problemów wynikłych w trakcie realizacji przepisów umów międzynarodowych i sprawującą nadzór merytoryczny nad realizacją tych umów przez instytucje właściwe. Działania te mają transgraniczny charakter i zmierzają do rozwiązywania wszelkich problemów, jakie mogą zaistnieć przy stosowaniu mechanizmów koordynacyjnych przez państwa członkowskie reprezentujące różne systemy ubezpieczeń społecznych, prowadzą do wymiany dobrych praktyk oraz idei w zakresie koordynacji systemów zabezpieczenia społecznego.

Stosując przepisy prawa dotyczące świadczeń z tytułu ubezpieczenia społecznego objętych zakresem przedmiotowym umów bilateralnych lub rozporządzeń unijnych, Zakład Ubezpieczeń Społecznych działa jako instytucja właściwa - czyli taka, w której osoba jest ubezpieczona w chwili składania wniosku i od której osoba ma prawo uzyskać świadczenie. Merytoryczne rozpoznanie wniosku o świadczenie z zastosowaniem mechanizmów koordynacji systemów zabezpieczenia społecznego zostało powierzone właśnie Zakładowi Ubezpieczeń Społecznych jako jednostce wyspecjalizowanej i organizacyjnie przygotowanej do realizacji tego rodzaju zadań.

$\mathrm{W}$ dalszym etapie postępowań $\mathrm{w}$ zakresie ubezpieczeń społecznych, po przyznaniu prawa do świadczenia $\mathrm{w}$ związku z migracją świadczeniobiorców, Zakład Ubezpieczeń Społecznych pełni funkcję instytucji miejsca zamieszkania, przez co należy rozumieć instytucję uprawnioną do udzielania emerytury lub renty w miejscu zamieszkania osoby zainteresowanej lub instytucję upoważnioną do udzielania emerytury lub renty zgodnie ze stosowanym przez nią ustawodawstwem.

W celu sprawnego wykonywania tych funkcji w ramach jednostek organizacyjnych Zakładu zostały powołane wskazane w Regulaminie organizacyjnym Zakładu ${ }^{18}$ jednostki realizujące umowy międzynarodowe (RUM), jako instytucje właściwe współpracujące z zagranicznymi instytucjami zabezpieczenia społecznego. Przed akcesją Polski do Unii Europejskiej funkcjonowało jedno Biuro Rent Zagranicznych w Centrali Zakładu, realizujące zadania wynikające z umów bilateralnych, natomiast od 2004 r. sukcesywnie zwiększana jest ilość RUM-ów w poszczególnych oddziałach ZUS, $\mathrm{z}$ uwagi na coraz większą liczbę ubezpieczonych posiadających w swoim zawodowym dorobku okresy ubezpieczenia, zamieszkania czy pracy w kra-

18 Regulamin organizacyjny Zakładu, https://bip.zus.pl/o-zus/regulamin-organizacyjny-zakladu (dostęp: 7.05.2019). 
jach Unii. Dzięki temu składając wniosek o emeryturę z polskiego systemu ubezpieczeń społecznych, z uwzględnieniem okresów podlegających koordynacji systemów zabezpieczenia społecznego, wnioskodawca składa go w dowolnej terenowej jednostce organizacyjnej ZUS, która jako instytucja właściwa i instytucja miejsca zamieszkania rozpoznaje wniosek. W Zakładzie Ubezpieczeń Społecznych wyznaczone zostały jednostki współpracujące z właściwymi instytucjami państw członkowskich przy rozpatrywaniu wniosków emerytalno-rentowych na podstawie rozporządzeń unijnych. Przykładowo oddział w Krakowie rozpoznaje wnioski z okresami holenderskimi, oddział w Opolu - z okresami niemieckimi, a oddział w Bydgoszczy - z okresami włoskimi.

Na tym polu wszystkie unormowania, począwszy od Traktatu o funkcjonowaniu Unii Europejskiej, poprzez rozporządzenia o koordynacji systemów zabezpieczenia społecznego, aż po normy krajowe, są tak skonstruowane, aby zapewnić maksymalne bezpieczeństwo ubezpieczeniowe jednostce. Istnieje jednak obszar, w którym na skutek działania lub zaniechania jednostki instytucja ubezpieczeniowa doznaje straty finansowej, której nie jest w stanie kompensować z innych źródeł. Chodzi mianowicie o świadczenia wypłacone po zgonie uprawnionego na rachunek bankowy w kraju zamieszkania świadczeniobiorcy przez zobowiązaną instytucję ubezpieczeniową innego kraju członkowskiego.

\section{Formularz „Oświadczenie emeryta/rencisty zamieszkałego za granicą 0 istnieniu dalszego prawa do pobierania świadczenia"}

Instrumentem, jaki posiadają instytucje ubezpieczeniowe państw członkowskich, służącym do „poświadczenia życia”, a tym samym do ustalenia istnienia dalszego prawa do świadczenia, są formularze „Oświadczenie emeryta/rencisty zamieszkałego za granicą o istnieniu dalszego prawa do pobierania świadczenia" (formularz polski). W polskim systemie prawnym jego podstawą prawną są art. 101 i 128 ustawy z dnia 17 grudnia 1998 r. o emeryturach i rentach z Funduszu Ubezpieczeń Społecznych ${ }^{19}$. Istota formularza sprowadza się do potwierdzenia przez właściwy urząd lub osobę w państwie zamieszkania świadczeniobiorcy własnoręczności podpisu osoby zamieszkałej za granicą i ma zapobiec wypłacaniu świadczenia tzw. martwym duszom.

Tego rodzaju oświadczenia, przygotowane przez ZUS w wersjach dwujęzycznych, po polsku i w języku odpowiedniego państwa członkowskiego, są wysyłane co roku, tradycyjną przesyłką listową za zwrotnym potwierdzeniem odbioru, do świadczeniobiorców polskiej instytucji ubezpieczeniowej zamieszkałych za granicą, z wyznaczonym terminem, do którego należy wypełniony druk odesłać. W przypadku niedochowania terminu ZUS

19 Tekst jedn.: Dz.U. z 2018 r. poz. 1270 ze zm. 
wstrzymuje wypłatę świadczenia. Zakład Ubezpieczeń Społecznych jest także na obszarze Rzeczpospolitej Polskiej instytucją, która dokonuje takich poświadczeń dla mieszkających w Polsce obywateli państw członkowskich, którym świadczenie wypłaca inna niż polska instytucja właściwa.

Problem pojawia się w sytuacji, gdy zgon świadczeniobiorcy nastąpi przed odesłaniem kolejnego druku, a instytucja ubezpieczeniowa wypłacająca to świadczenie nie zostanie poinformowana o tym fakcie. Tego rodzaju nadpłaty w transgranicznym transferze świadczeń są niestety nieuniknione. Co istotne w takiej sytuacji, instytucje ubezpieczeniowe nie są w stanie odzyskać tych środków z zagranicznych banków. Wynika to niewątpliwie z faktu, że rozporządzenia unijne w zakresie koordynacji systemów zabezpieczenia mają właśnie koordynacyjny, a nie harmonizujący charakter. W obszarze odzyskania nadpłaconych środków z zagranicznych banków każda instytucja ubezpieczeniowa zobowiązana jest stosować przepisy wewnętrzne państwa członkowskiego, do którego kierowała świadczenie. W rzeczywistości środki te są nie do odzyskania ${ }^{20}$. Konieczność działania instytucji zabezpieczenia społecznego po zgonie świadczeniobiorcy jest pochodną jego prawa do świadczenia z koordynowanych systemów zabezpieczenia społecznego i konsekwencją ustania prawa do tego świadczenia. Mechanizm koordynacji systemów zabezpieczenia społecznego jest zorientowany jedynie na linii ubezpieczony - instytucja ubezpieczeniowa, ale już nie na linii instytucja ubezpieczeniowa - bank. Wpływa to niekorzystnie na stan finansów publicznych, jakimi w racjonalny sposób dysponować mają instytucje ubezpieczeniowe wszystkich objętych unijną koordynacją krajów.

Koordynacja zapewnia łączność między ustawodawstwami krajowymi państw członkowskich ${ }^{21}$. Obecnie w większości przypadków wymiana informacji pomiędzy instytucjami ubezpieczeniowymi państw członkowskich odbywa się $\mathrm{w}$ formie papierowej za pomocą formularzy łącznikowych, tradycyjną przesyłką pocztową i dotyczy informacji koniecznych do objęcia ubezpieczeniem i nabycia prawa do świadczenia. Aby dostosować pracę instytucji ubezpieczeniowych do zmieniającej się sytuacji społecznej (kiedy także po nabyciu prawa do emerytury czy renty nie ustaje mobilność świadczeniobiorców) i zwiększyć skuteczność wymiany informacji w zakresie koordynacji systemów zabezpieczenia społecznego, stworzono system elektronicznej wymiany informacji dotyczących zabezpieczenia społecznego EESSI (ang. Electronic Exchange of Social Security Information). Przekazywanie danych między instytucjami lub instytucjami łącznikowymi odbywać się ma drogą elektroniczną, w sposób bezpośredni lub za pośrednictwem punktów kontaktowych w ramach wspólnej bezpiecznej sieci, która może zapewnić poufność i ochronę wymiany danych. Struktu-

20 Szerzej zob. A. Szybkie, Zwalczanie błędów i nadużyć..., s. 19-31.

21 G. Uścińska, Europejskie standardy zabezpieczenia społecznego a wspótczesne rozwiązania polskie, Warszawa 2005, s. 512. 
rę, zawartość, format oraz szczegółowe ustalenia dotyczące wymiany dokumentów i standardowych dokumentów elektronicznych (SED) oraz uzgodnienia procedur biznesowych (BUC) ustala Komisja Administracyjna (powołana mocą art. 71 rozporządzenia nr 883/2004). Trzysta dwadzieścia standaryzowanych druków dokumentów wymiany informacji między właściwymi instytucjami państw członkowskimi oraz sto dwadzieścia procedur ${ }^{22}$ ma $\mathrm{z}$ jednej strony usprawnić prace instytucji właściwych, a $\mathrm{z}$ drugiej strony zapewnić wnioskodawcom bezpieczeństwo w postaci kompletności informacji niezbędnych instytucjom właściwym, niezależnie od kraju członkowskiego, w którym wnioskodawca złoży wniosek o świadczenie.

Centralny system EESSI został udostępniony przez Komisję Europejską w lipcu 2017 r. Państwa członkowskie mają dwa lata na jego wdrożenie EESSI oraz na umożliwienie swoim instytucjom zabezpieczenia społecznego transgranicznej elektronicznej wymiany informacji ${ }^{23}$ przy obsłudze spraw indywidualnych realizowanych w ramach koordynacji systemów zabezpieczenia społecznego. Z założenia system EESSI ma obejmować wyłącznie wymianę danych pomiędzy instytucjami zabezpieczenia społecznego i nie dotyczy kontaktów instytucji z klientami. Elektroniczna wymiana danych ma dotyczyć wymiany informacji, dokumentów i oświadczeń niezbędnych do rozpatrzenia uprawnień do świadczeń na podstawie rozporządzenia nr 883/2004. Chodzi o kwestie podlegania właściwemu ustawodawstwu, przyznawania i wypłaty świadczeń, jak również transgranicznego dochodzenia należności z tytułu nieopłaconych składek i nadpłaconych świadczeń ${ }^{4}$, rozumianych jako wyłudzenia świadczeń i zapomóg na terenie państw UE.

Istotne dla omawianego problemu jest to, że instytucje ubezpieczeniowe mają udzielać sobie nawzajem informacji na wniosek lub zapytanie innej instytucji ubezpieczeniowej. W przypadku informacji o zgonie świadczeniobiorcy inicjatywa przekazania informacji powinna leżeć po stronie tej instytucji, która powzięła taką informację i musi dokonana być niezwłocznie. W myśl art. 76 rozporządzenia nr 887/2004 udzielenie informacji na zapytanie lub wniosek innej instytucji ubezpieczeniowej powinno nastąpić „w rozsądnym terminie”. Polski ustawodawca posługuje się terminem „niezwłocznie”, co budzić może uzasadnione wątpliwości co do faktycznego rozumienia terminu, w którym należy udzielić odpowiedzi. Niemniej jednak

22 Materiały z konferencji: 2nd ELRC Conference Agenda, 26.11.2016, Brussels, Phil Cummings Franciska Barabas-Komives, http://www.lr-coordination.eu/ sites/default/files/Brussels_conference/Barabas-Komives-F_EESSI\%20-\%202nd\%20 ELRC\%20Conference_20161024.pdf (dostęp: 2.09.2019).

23 System elektronicznej wymiany informacji dotyczacych zabezpieczenia społecznego (EESSI), https://ec.europa.eu/social/main.jsp?catId=869\&langId=pl (dostęp: 1.05.2019).

24 Odpowiedź na interpelację nr 11786 w sprawie wyłudzeń zasiłków i zapomóg socjalnych od państwa, http://search.sejm.gov.pl/SejmSearch/ADDL.aspx?DoSearchNewByIndex (dostęp: 2.09.2019). 
ważne jest, że wśród standardowych dokumentów elektronicznej wymiany informacji na podstawie art. 76 rozporządzenia nr 887/2004 opracowano formularz H070 - powiadomienie o zgonie. Dokument przygotowany jest do wymiany informacji pomiędzy instytucjami zabezpieczenia społecznego, powziętych od zainteresowanych przebywających na terenie jednego z państw członkowskich, a istotnych dla instytucji zabezpieczenia społecznego innego państwa członkowskiego. W części pierwszej druk powiadomienia o zgonie zawiera dane identyfikacyjne osoby zmarłej, w tym kraj pochodzenia, oraz dane identyfikacyjne instytucji, do której kierowana jest informacja. W drugiej części podaje się datę i miejsce zgonu (adres), państwo oraz umieszcza dodatkowe informacje, jeśli zajdzie taka konieczność. Istnieje także możliwość załączenia dokumentów (w wersji elektronicznej) potwierdzających zgon.

Wydaje się, że taki dokument elektronicznej wymiany informacji ma szansę sprawdzić się w sytuacji informowania o zgonie, jednak jego skuteczność będzie zależeć nie tylko od przekazania informacji między instytucjami zabezpieczenia społecznego w rozsądnym terminie, ale także od tego, w jakim terminie osoby zainteresowane (członkowie rodziny) przekażą informację o zgonie do którejkolwiek z instytucji zabezpieczenia społecznego objętej koordynacją unijną. Taka forma przekazywania informacji niewątpliwie skróci okresy wypłacania świadczeń po zgonie, jednak nie zniweluje problemu całkowicie. Nie daje także skutecznego narzędzia w dochodzeniu zwrotu takich świadczeń bezpośrednio od banków w krajach, do których zostały transferowane.

\section{Podsumowanie}

Przygotowana w wąskim zakresie na podstawie koordynacji systemów zabezpieczenia społecznego procedura poświadczania dalszego prawa do świadczenia jest dotychczas mało wydajna, a wielu przypadkach nieskuteczna. Pomimo prac Komisji Administracyjnej w obszarze informacji o zgonie świadczeniobiorcy podjęte działania są niewystarczające. Stworzona została platforma H5NCP do walki z błędami i nadużyciami, która służy jako miejsce do zgłaszania uwag, problemów, wymiany dobrych praktyk czy pomysłów, ale nie do wymiany informacji, tak jak w przypadku wymiany danych o okresach ubezpieczenia na potrzeby przyznania prawa do świadczenia. Wydaje się, że spośród dotychczas podjętych działań najbardziej efektywna będzie elektroniczna wymiana informacji o zgonie świadczeniobiorcy bezpośrednio między instytucjami ubezpieczeniowymi poszczególnych państw członkowskich. Jednak niewątpliwym sukcesem $\mathrm{w}$ dziedzinie walki $\mathrm{z}$ nadużyciami i dbałości o finanse publiczne byłyby zmiany systemowe w obrębie całej Unii w zakresie prawa bankowego, które dawałoby instytucjom zabezpieczenia społecznego prawne możliwości 
odzyskania kwot świadczeń wypłaconych na rachunek bankowy po zgonie osoby uprawnionej.

Inną możliwość dbania o interesy krajowych instytucji zabezpieczenia społecznego stwarzałaby sytuacja, w której instytucje te reprezentowałyby wzajemnie swoje interesy na gruncie prawa krajowego. Współcześnie ukształtowany system koordynacji zabezpieczenia społecznego nie daje takich możliwości, ponieważ brak jest regulacji dotyczących koordynacji w relacjach pochodnych, następczych względem procesu przyznania i wypłaty świadczenia objętego taką koordynacją. Warto więc, aby przynajmniej w omawianym zakresie, mając na uwadze zasady dotyczące funkcjonowania administracji publicznej państw członkowskich, w europejskiej przestrzeni administracyjnej pojawiły się rozwiązania zmierzające do konwergencji pomiędzy krajowymi systemami prawa ${ }^{25} \mathrm{w}$ obrębie zwrotu świadczeń nadpłaconych wskutek braku informacji o zgonie świadczeniobiorcy.

\section{Bibliografia}

Gac M., Europejska przestrzeń administracyjna jako mechanizm zwiększajacy efektywność stosowania prawa Europejskiej Sieci Konkurencji, „Rocznik Administracji Publicznej" 2015, nr 1.

Regulamin organizacyjny Zakładu, https://bip.zus.pl/o-zus/regulamin-organizacyjny-zakladu.

Roicka P., Skutki swobody przepływu osób w UE dla krajowych systemów zabezpieczenia społecznego. Wybrane zagadnienia, „Ubezpieczenia Społeczne. Teoria i Praktyka" 2015, nr 3 (126).

System elektronicznej wymiany informacji dotyczacych zabezpieczenia społecznego (EESSI), https://ec.europa.eu/social/main.jsp?catId=869\&langId=pl.

Szybkie A., Materialnoprawny wpływ koordynacji systemów zabezpieczenia społecznego UE na krajowe instytucje prawne zabezpieczenia społecznego, „Ubezpieczenia Społeczne. Teoria i Praktyka" 2017, nr 4 (135).

Szybkie A., Zwalczanie błędów i nadużyć zwiazanych z koordynacja systemów zabezpieczenia społecznego $w$ Unii Europejskiej na przykładzie przeciwdziałania nadpłatom emerytur na zagraniczne rachunki bankowe, „Ubezpieczenia Społeczne. Teoria i Praktyka" 2018, nr 2 (137).

Ślebzak K., Koordynacja systemów zabezpieczenia społecznego, Warszawa 2012.

Świątkowski A.M., Obywatelstwo Unii Europejskiej a prawo do świadczeń z zabezpieczenia społecznego, „Studia z Zakresu Prawa Pracy i Polityki Społecznej” 2008.

Ustalanie właściwego ustawodawstwa na podstawie rozporzadzeń 1408/71 i 574/72, https://www.zus.pl/pracujacy/pracujacy-w-ue-eog-szwajcarii/archiwum/ ustalanie-wlasciwego-ustawodawstwa-na-podstawie-rozporzadzen-1408/ 71-i-574/72 (dostęp: 29.04.2019).

25 M. Gac, Europejska przestrzeń administracyjna jako mechanizm zwiększający efektywność stosowania prawa Europejskiej Sieci Konkurencji, „Rocznik Administracji Publicznej" 2015, nr 1, s. 97. 
Uścińska G., Europejskie standardy zabezpieczenia społecznego a współczesne rozwiązania polskie, Warszawa 2005.

Uścińska G., Zabezpieczenie społeczne osób korzystających z prawa do przemieszczania się w Unii Europejskiej, Warszawa 2013.

Akty prawne

Traktat o funkcjonowaniu Unii Europejskiej, wersja skonsolidowana Dz.Urz. UE z 2016 r. C 202, s. 47.

Rozporządzenie Rady (EWG) nr 1408/71 z dnia 14 czerwca 1971 r. w sprawie stosowania systemów zabezpieczenia społecznego do pracowników najemnych, osób prowadzących działalność na własny rachunek i do członków ich rodzin przemieszczających się we Wspólnocie, Dz.Urz. UE L 149, s. 2, ze zm.

Rozporządzenie Rady (EWG) nr 574/72 z dnia 21 marca 1972 r. w sprawie wykonywania rozporządzenia (EWG) nr 1408/71, Dz.Urz. UE L 74, s. 1, ze zm.

Rozporządzenie Rady (WE) nr 859/2003 z dnia 14 maja 2003 r. rozszerzające przepisy rozporządzenia (EWG) nr 1408/71 i rozporządzenia 574/72 na obywateli państw trzecich, którzy nie są jeszcze objęci tymi przepisami wyłącznie ze względu na ich obywatelstwo, Dz.Urz. WE L 124, s. 1.

Rozporządzenie Rady i Parlamentu Europejskiego (WE) nr 883/2004 z dnia 29 kwietnia 2004 r. w sprawie koordynacji systemów zabezpieczenia społecznego, Dz.Urz. UE L 166, s. 1, ze zm.

Rozporządzenie Rady i Parlamentu Europejskiego nr 987/2009 z dnia 16 września 2009 r. dotyczące wykonywania rozporządzenia (WE) nr 883/2004 w sprawie koordynacji systemów zabezpieczenia społecznego, Dz.Urz. UE L 284, s. 1, ze zm.

Rozporządzenie Parlamentu Europejskiego i Rady (UE) nr 1231/2010 z dnia 24 listopada $2010 \mathrm{r}$. rozszerzające rozporządzenie (WE) nr 882/2004 i rozporządzenie (WE) nr 987/2009 na obywateli państw trzecich, którzy nie są jeszcze objęci tymi rozporządzeniami jedynie ze względu na swoje obywatelstwo, Dz.Urz. UE L 344, s. 1.

Ustawa z dnia 13 października 1998 r. o systemie ubezpieczeń społecznych, tekst jedn.: Dz.U. z 2019 r. poz. 300 ze zm.

Ustawa z dnia 17 grudnia 1998 r. o emeryturach i rentach z Funduszu Ubezpieczeń Społecznych, tekst jedn.: Dz.U. z 2018 r. poz. 1270 ze zm.

Ustawa z dnia 8 listopada 2013 r. o zmianie niektórych ustaw w związku z wdrożeniem Systemu Elektronicznej Wymiany Informacji dotyczących Zabezpieczenia Społecznego na terytorium Rzeczypospolitej Polskiej, Dz.U. poz. 1623.

Streszczenie

Stworzony w Unii Europejskiej system koordynacji krajowych przepisów zabezpieczenia społecznego jest gwarantem bezpieczeństwa ubezpieczeniowego osób migrujących. Są jednak obszary, które nie zostały objęte systemem koordynacji, a które dopiero odkrywa praktyka. Celem niniejszego artykułu jest wskazanie na jedną z procedur, której konsekwencje nie są objęte systemem unijnej koordynacji. Potocznie nazywana „poświadczeniem życia” ma istotne znaczenie dla instytucji zabezpieczenia społecznego 
każdego państwa członkowskiego, ponieważ rodzi negatywne skutki finansowe po stronie instytucji zabezpieczenia społecznego.

Słowa kluczowe: koordynacja systemów zabezpieczenia społecznego, system zabezpieczenia społecznego, swoboda przepływu osób, poświadczenie życia, elektroniczna wymiana informacji w zakresie zabezpieczenia społecznego (EESSI)

\section{Coordination of Social Security Systems in Derivative Relations}

Abstract

The system of coordination of national legal regulations relevant to social security developed in the European Union is a guarantee of the security of migrating individuals. Nevertheless, there are areas which are not covered by the coordination system in question, and which are being discovered by practitioners only now. The objective of this article is to indicate one of the procedures the consequences of which are not covered by the EU system of coordination. Informally referred to as 'the certificate of life', it is of major significance for social security institutions in all Member States because it has negative financial consequences for them.

Keywords: coordination of social security systems, social security system, freedom of movement, certificate of life, Electronic Exchange of Social Security Information EESSI. 